\title{
Estimating the New Keynesian Model by Bootstrap Method for Johor Economy Tourism
}

\author{
Lola Muhamad Safiih, Hussin Mohd Fadli, Zainuddin Nurul Hila, Ramlee Mohd Noor Afiq \\ School of Informatics and Applied Mathematics, University of Malaysia, Terengganu, Malaysia \\ Email: safiihmd@umt.edu.my, mohdfadlihussin@gmail.com, hila.zainuddin@gmail.com, afiqramlee91@gmail.com
}

How to cite this paper: Muhamad Safiih, L., Mohd Fadli, H., Nurul Hila, Z. and Mohd Noor Afiq, R. (2016) Estimating the New Keynesian Model by Bootstrap Method for Johor Economy Tourism. Modern Economy, 7, 1061-1069.

http://dx.doi.org/10.4236/me.2016.710108

Received: July 23, 2016

Accepted: September 6, 2016

Published: September 9, 2016

Copyright $\odot 2016$ by authors and Scientific Research Publishing Inc. This work is licensed under the Creative Commons Attribution International License (CC BY 4.0).

http://creativecommons.org/licenses/by/4.0/

(c) (i) Open Access

\begin{abstract}
The use of Keynesian Model (KM) is exposed to large error value as well as wide confidence intervals, which may affect the accuracy of the results. Therefore, this paper attempts to hybridize bootstrap approach with Keynesian Model to obtain accurate estimation results which are known as the Bootstrap Keynesian Model (BKM). The proposed model is applied to the data of Johor Economic Tourism. The findings indicate that the Bootstrap Keynesian Model is the best model compared to the Keynesian Model since the error produced using the Bootstrap Keynesian Model is smaller and the confidence intervals are shorter. This shows that the proposed model is best to use in the measurement of multiplier. It can be concluded that the application of MK with bootstrap method is very useful to provide more accurate decisions. Therefore, the multipliers obtained may provide useful information for policy makers and researchers in the field of tourism.
\end{abstract}

\section{Keywords}

Bootstrap Method, Bootstrap Keynesian Model, Multiplier, Economic Tourism, Simulation

\section{Introduction}

Tourism industry in Malaysia has been recorded as one of the largest contributors to the growth and the development of national economy [1] [2]. It is reported that the Malaysia's tourism has collected a moderate gross domestic product (GDP) in 2015, where it is found that $57.7 \%$ of foreign visitor and $42.3 \%$ of domestic visitor spend their holidays in this Asian country [3]. Aware of this positive GDP, Malaysia government takes the opportunity to construct various developments of tourism project and eventually, most of the projects highlighted Johor due to its most preferable visited state. 
According to [4], the development projects are expected to attract more visitors either from domestic or foreign, to make Johor as a preferred destination of world tourism.

Considering to this positive development project, this research is conducted to study the impact of tourism on Malaysia economy through multiplier value that obtained from Keynesian model and to examine the relationship between parameters of this model.

Keynesian model is well-known as a macroeconomic model, which was introduced by the economist John Maynard Keynes in 1936, during the Great Depression effects on the Second World War around 1929 [5]. Keynes advocated that higher government spending and lower taxes could stimulate demand, thus could the global economy from further decline. Moreover, investments by government in infrastructure development were able to inject revenue and create business opportunities, jobs and demand [6].

However, Keynesian Model tends to produce a large error and effect on the estimation of the multiplier value. Hence, to overcome this problem, the bootstrap approach is introduced and hybridized with Keynesian Model. Bootstrap method is expected to reduce the error [7]. This hybrid model is called Bootstrap Keynesian Model.

\section{Methodology}

\subsection{The Keynesian Model (KM)}

The Keynesian Model (KM) has opened the eyes of many economists to be studied in greater depth. Various improvements and transformations are involved in this model. Thus, in 1997, this model was modified by McDonald's where this model includes four equations, i.e. consumption, investment, imports and taxes. Overall four of this equation sum up in the expression of national income [8]. The equations of the model can be referred to as the following recursive:

$$
\begin{gathered}
Y_{t}=C_{t}+I_{t}+G_{t}+T r_{t}+X_{t}-M_{t} \\
C_{t}=c_{0}+c_{1} Y_{d}+\varepsilon \\
I_{t}=i_{0}+i_{1} Y_{t}+\varepsilon \\
M_{t}=m_{0}+m_{1} Y_{t}+\varepsilon \\
T_{t}=t_{0}+t_{1} Y_{t}+\varepsilon \\
Y_{d}=Y_{t}-T_{t} .
\end{gathered}
$$

This model consists of 6 equations. Equation (1) shows that endogenous variable can be seen on the left side which is national income, $Y_{t}$ and there are six exogenous variables i.e. consumption $\left(C_{t}\right)$, investment $\left(I_{t}\right)$, import $\left(M_{t}\right)$ government spending $\left(G_{t}\right)$, tourism revenue ( $\left.\operatorname{Tr}_{t}\right)$ and export $\left(X_{t}\right)$. Equation (2) shows the consumption, $C$, which, depending on disposal income $\left(Y_{d}\right)$, where $C_{1}$ is the marginal propensity to consume. Equation (3) shows the investment, $I_{t}$ where it is positively correlated to $Y_{t}$ where $i_{1}$ is the marginal propensity to invest. Equation (4) shows the import, $M_{t}$ which is also positively correlated to $Y_{t}$ and depends on the marginal propensity to import, $m_{1}$. 
Equation (5) shows the tax, $t_{1}$ which depend on $Y_{t}$ where $t_{1}$ is a tax rate. Autonomy component for consumption, investment, import and tax is known as $c_{0}, i_{0}, m_{0}$ and $t_{0}$. An error term, $\varepsilon$ in each equation tends to produce high error and affects the estimation of multiplier. Thus, the bootstrap approach is used to overcome this problem. These parameters are analyzed using ordinary least squares (OLS) method. The value of the estimated parameters is further used to obtain an estimated value for tourism income multiplier $\left(k_{T r}\right)$ as the following recursion:

$$
k_{T r}=\frac{1}{1-c_{1}\left(1-t_{1}\right)-i_{1}+m_{1}} .
$$

Any increase in $c_{1}$ or $i_{1}$ will lead to an increase in the value of the multiplier. At the same time, any increase in $m_{1}$ or $t_{1}$ will reduce the value of the multiplier. Tourism multipliers are measured by the present economic performances in the tourism industry and the short-run economic effects of changes in the level of tourism. The purpose of tourism multipliers is twofold; firstly, to study the economic impact of tourism expenditure, particularly on business turnover, incomes, employment, public sector revenue and imports. Secondly, they are concerned with the effects of short-run adjustment to a change in tourism expenditure and can provide a wealth of information of value to policymakers and planners [9]. The tourism income multiplier can be classified according to the research of [10], where the respective multiplier of $k_{T r} \geq 1,0<k_{T r}>1$ and $k_{T r}=0$ are development factor, parasitic factor and tourism enclave. Moreover, the multiplier for consumption $\left(k_{C}=c_{1} \cdot k_{T r}\right)$, the multiplier for investment $\left(k_{I}=i_{1} \cdot k_{T r}\right)$ and multiplier for import $\left(k_{M}=m_{1} \cdot k_{T r}\right)$ were estimated based on the value of the tourism income multiplier. In this research, ranges of multiplies are considered to follow [3], where the respective ranges of low, medium and high multiplier are $(0.1-0.3),(0.4-0.6)$ and $(0.7-1.0)$.

\subsection{The Bootstrap Approach}

In this research, the bootstrap approach is hybridizing into the Keynesian model in order to develop a new model of the Bootstrap Keynesian Model (BKM). As well as a standard model, this BKM is consists four important elements; 1) bootstrap of consumption $\left.\left(\mathrm{C}^{B}\right), 2\right)$ bootstrap of investment $\left.\left(\mathrm{I}^{B}\right), 3\right)$ bootstrap of $\operatorname{tax}\left(\mathrm{T}^{B}\right)$ and 4) bootstrap of import $\left(\mathrm{M}^{B}\right)$. The bootstrap scheme that is used is a residual scheme, and its adapted procedure is focusing to obtained new set sample data for BKM.

Let $\left\{C_{t}=C_{1}, \cdots, C_{n}\right\}$ with $t=1, \cdots, n$ is a set of generated sample data from unknown distribution of consumption equation, $C$. This sample is considered to be used in estimating the parameters $\left\{c_{0}, c_{1}\right\}$ and residual model of $\varepsilon_{c_{t}}=C_{t}-\hat{C}_{t}$. Next, the residual is considered to be re-sampled for $B$ replication, for instance, $B=1000$. The purpose of this re-sampling procedure is to obtain a set of bootstrap sample data of $Y_{d_{t}}^{B}$, and by using this data, the parameter of $c_{0}$ and $c_{1}$ can be estimated using an ordinary least square method, refer to [3] [7] [11]. At the end of this procedure, a bootstrap of consumption can be obtained and can be given by following recursion: 


$$
\hat{C}_{t}^{B}=c_{0}+c_{1} \hat{Y}_{d_{t}}+\hat{\varepsilon}_{c_{t}}^{B} .
$$

The same procedure is repeated for estimating the $\mathrm{I}^{B}, \mathrm{~T}^{B}$ and $\mathrm{M}^{B}$. All of these steps of estimation can be refers to the alternative procedure of the residual bootstrap scheme which was introduced by [11]. Each of these elements, test its accuracy using the error estimation and confidence interval. In terms of error estimation, this research is motivated by methods of mean squared error and root mean squared error that was used by [12]:

$$
\begin{gathered}
M S E=\frac{\sum_{i=1}^{N}\left[C_{i_{m c s}}-\hat{C}_{i_{\text {mcs }}}\right]^{2}}{N} \\
R M S E=\sqrt{\frac{\sum_{i=1}^{N}\left[C_{i_{\text {mes }}}-\hat{C}_{i_{m c s}}\right]^{2}}{N} .}
\end{gathered}
$$

Meanwhile, the two-sided of $90 \%$ confidence interval of standard and bootstrap method are considered as the following recursion:

1) Standard confidence interval method:

$$
\begin{gathered}
{\left[\hat{\theta}_{B}, \hat{\theta}_{A}\right]=\left[\hat{\theta}-Z^{1-\alpha} \cdot S \hat{E}, \hat{\theta}+Z^{\alpha} \cdot S \hat{E}\right]} \\
{\left[\hat{\theta}_{B(T)}, \hat{\theta}_{A(T)}\right]=\left[\hat{\theta}-t_{n-1}^{1-\alpha} \cdot S \hat{E}, \hat{\theta}+t_{n-1}^{1-\alpha} \cdot S \hat{E}\right]}
\end{gathered}
$$

where $\left[\hat{\theta}_{B}, \hat{\theta}_{A}\right]$ and $\left[\hat{\theta}_{B(T)}, \hat{\theta}_{A(T)}\right]$ refer to normal and studentised method respectively.

2) Bootstrap confidence interval method:

$$
\begin{gathered}
{\left[\hat{\theta}_{B(P B)}, \hat{\theta}_{A(P B)}\right]=\left[\hat{\theta}^{50}, \hat{\theta}^{950}\right]} \\
{\left[\hat{\theta}_{B(B C a)}, \hat{\theta}_{A(B C a)}\right]=\left[\hat{\theta}^{\left(\alpha_{1}\right)}, \hat{\theta}^{\left(\alpha_{2}\right)}\right]}
\end{gathered}
$$

where $\left[\hat{\theta}_{B(P B)}, \hat{\theta}_{A(P B)}\right]$ and $\left[\hat{\theta}_{B(B C a)}, \hat{\theta}_{A(B C a)}\right]$ refer to percentile bootstrap (PB) and bias corrected and acceleration ( $\mathrm{BCa}$ ) method respectively. The value of $\alpha_{1}$ and $\alpha_{2}$ in Equation (13) is depends on the replication number, $B$.

\section{Literature Review}

Several previous studies have investigated tourism impact through multiplier value. Ref. [13] had studied the Singapore tourism multiplier using Keynesian model based on a tourism data starting from 1983. The value of tourism multiplier is used to compare with the previous study in Singapore. The estimated multipliers for tourism in Singapore are quite high and the comparative results tend to suggest that the economic importance of tourism in Singapore has increased over the years. Although input-output analysis provides an excellent framework for measuring the impact of a multiproduct industry such as tourism, it has several limitations. Technical coefficients are assumed to be constant and a single homogeneous production function is assumed to hold for each sector. 
Ref. [11] did a research which examined the impact of tourism revenue towards economy in Egypt by using Keynesian Model. They had used economic data in Egypt from year 1972 till 1990. The parameter was estimated by using three-stage least square method to find the multiplier value. The value then was used in tourism model that has been developed by using System Dynamic to study the relationship of each parameter in a system. Thus, these developed model can be used to help in teaching strategy, economic learning and can help professional policy maker in making decision.

In 2003, ref. [14] had conducted a study about the economic impact of cruise tourism on Jamaica. This study had used Keynesian Model to find the tourism multiplier value. Thus, three regressions for three different multipliers are used to study the economic impact of cruise tourism on Jamaica. Overall of the study found that cruise tourism had an impact on import and investment. It can be seen through construction of big projects in Royal Port, Jamaica resulted from huge investment.

Ref. [15] researched on tourism impact and macroeconomic parameter towards growing economy in Nepal by using Keynesian Model. The multiplier values were estimated using three stages least square method by using data from year 1975 till 2010. In this study, Granger causality test is used to ensure that the impact of other variables which the study found that tourism has a two-way relationship between variables such as exports, consumption, imports, and others.

\section{Empirical Analysis}

\subsection{Johor Tourism Data}

In this research, Johor tourism data is used to analyze the impact of tourism revenue in Johor and study the relative impact on income, consumption, investment and imports. The model will be analyzed using annual time series covering the period from 2000 till 2010. All the variables of the model will be measured in million Ringgit Malaysia. The data are taken from Iskandar Malaysia, National Audit Department of Johor, Johor Tourism Department and Department of Statistic Malaysia. Equations (2) to (5) are analyzed using an ordinary least Squares (OLS) method. This correlation will account for the random variables so we can be sure that the parameters that have been chosen efficiently and consistently [7] [16] [17].

\subsection{Numerical Results}

MSE and RMSE are used in order to estimate the accuracy of BKM. Further details on these values are summarized in Table 1.

Based on Table 1, it's shown that the bootstrap model provides the smallest error value compared to the real model, KM (C, I, M and T). For example, the estimation result for RMSE of new models, $\mathrm{C}^{\mathrm{B}} 0.00073558$ while the real model gives a large error estimation, which is 0.01835182 . From this result, the MBK is found to have higher accuracy compared to the standard model of KM. It is because a model that gives the smallest estimated value is said to be more efficient [17]. 
Table 1. Error estimation of Bootstrap Keynesian Model (BKM).

\begin{tabular}{cccccccccc}
\hline & \multicolumn{8}{c}{ Model estimation } \\
\hline & $\mathrm{C}$ & $\mathrm{C}^{B}$ & $\mathrm{I}$ & $\mathrm{I}^{B}$ & $\mathrm{M}$ & $\mathrm{M}^{B}$ & $\mathrm{~T}$ & $\mathrm{~T}^{B}$ \\
\hline MSE & $0.00034^{\mathrm{a}}$ & $5.41 \mathrm{E}-70$ & $0.00074^{\mathrm{b}}$ & $8.51 \mathrm{E}-07$ & 0.00215 & $2.16 \mathrm{E}-06$ & $2.87 \mathrm{E}-05$ & $2.61 \mathrm{E}-08$ \\
RMSE & 0.01835 & 0.00074 & 0.02727 & $0.00092^{\mathrm{c}}$ & 0.04641 & 0.00147 & 0.00536 & $0.00016^{\mathrm{d}}$ \\
\hline
\end{tabular}

${ }^{\mathrm{a}, \mathrm{b}} \mathrm{Refer}$ to the estimation result of standard model. ${ }^{\mathrm{c}, \mathrm{d}}$ Refer to estimation of the bootstrap model.

Based on Table 2, it is found that the estimate for the standard intervals which is a confidence interval gives a shorter interval for all hybrid models. For example, the length of BT- $t$ valued 0.037150 compare to real model, T- $t$ which is more lengthen, 0.486423 . The comparison of length estimation of I and $\mathrm{T}$ using the standard interval method, shown to have slightest differs length, i.e. (I-Normal $=0.4804635$, I-Studentised $=0.4804634)$ and $(\mathrm{I}-$ Normal $=0.4864235$, I-Studentised $=0.4864234)$. Meanwhile, the $\mathrm{I}^{B}$ and $\mathrm{T}^{B}$ show a greater different length. The differences shown in these models proved that the bootstrap approach fixed the interval estimation and gives a good performance for the hybrid model. It is also found that the BCa method can provide better performance. This is proven by the estimated length that is found to be the shortest among other method.

\subsection{Tourism Income Multiplier and Johor Tourism Impact Analysis}

Johor is, no doubt, one of the popular tourist destinations with full potentialities. The magnitude of the multiplier depends on the higher earnings from tourism, retention of earnings, strong backward and forward interlinked among major sectors of an economy [15]. In this study, the economic impact of tourism Johor can be seen in the multiplier derived from the economic model of the Keynesian model. Hence, to increase the accuracy of the estimator, the bootstrap method is used.

In order to determine the value of the tourism multiplier in Johor, the parameters of the marginal propensities of consumption, investment, imports and tax rate are estimated, and the respective estimation value are 0.15994, 0.39423, 0.06159 and 0.09557 . Based on this estimation, the income multiplier for tourism is found to be 1.91 . The values of marginal propensities revealed that there is a positive effect on consumption, investment, imports and tax rate in gross domestic product. The value of marginal propensity to consume shows that increases in GDP by RM1 lead to a 15 cent increase in consumption. So new money injected from exports, remittances and tourism has stimulated the consumption of imported goods. The value of marginal propensity to import shows that out of RM1 increase in GDP, 6 cents is spent for imports of goods and services. The greatest effect of the high marginal propensity to import resulted in the lower value of the tourism multiplier. Taxes and imports are regarded as the leakages on the multiplier analysis [15]. The value of the tourism income multiplier which is 1.91 can be conclude that increasing in one unit of tourism spending can produce more than one unit of income. This situation illustrates that the tourism sector such as transportation, services, hotel, food, island and entertainment in Johor could attract 
more tourist subsequently inject more sustainable economy. According to [9] [10] [13], the tourism multiplier reported in Canada (2.5), Turkey (1.96), United Kingdom (1.73), Hong Kong (1.02), Egypt (1.23) and Iceland (0.64). The results of the multiplier for Johor tourism data can be referred in Table 3.

Based on Table 3, the multiplier for consumption is 0.31 . This means that every RM1 billion of new revenue could generate tourism income of RM 0.31 billion. Next, the investment multiplier is 0.75 . This indicated that an addition of RM1 billion in investments in the state of Johor can inject about RM0.75 billion in tourism income. The import multiplier for the Johor tourism sector recorded a value of 0.12 . This means that with an increase in the value of imports of RM1 billion will contribute to Johor tourism income of RM 0.12 billion [18].

\section{Conclusion}

In this paper, bootstrap approach is hybridized into Keynesian Model and produces new model which is a Bootstrap Keynesian Model, BKM. Hence, to test the performance of the bootstrap approach towards $\mathrm{MK}$, we are comparing the method developed by the existing model through statistical estimation and calculation of interval estimated by using Monte Carlo simulation. The result showed that MBK met the criteria of estimation which are consistent and efficient. Next, Johor tourism economic data are applied in BKM and multiplier value is estimated. The result showed that the estimated value of tourism multiplier using bootstrap approach was high as compared to existing models. However, the accuracy of the results depends on the adequacy of the data. Apart from data difficulties, the accuracy of the results depends on how well the model has been specified

Table 2. Interval estimator in Johor tourism data.

\begin{tabular}{|c|c|c|c|c|c|c|c|c|}
\hline & $\mathrm{C}$ & $\mathrm{C}^{B}$ & I & $\mathrm{I}^{B}$ & M & $\mathbf{M}^{B}$ & $\mathrm{~T}$ & $\mathrm{~T}^{B}$ \\
\hline \multirow{2}{*}{\multicolumn{9}{|c|}{$\begin{array}{l}\text { (a) Standard } \\
\text { Interval: }\end{array}$}} \\
\hline & & & & & & & & \\
\hline Normal & $1.09656^{\mathrm{a}}$ & 0.04979 & 0.48046 & $0.13944^{c}$ & 0.55483 & 0.02182 & 0.48642 & 0.03333 \\
\hline Studentised & 1.22207 & 0.05549 & $0.48046^{\mathrm{b}}$ & 0.15541 & 0.55483 & 0.02431 & 0.48642 & 0.03715 \\
\hline \multicolumn{9}{|l|}{ (b) Bootstrap } \\
\hline \multicolumn{9}{|l|}{ Interval: } \\
\hline $\mathrm{PB}$ & & 0.01279 & & $0.02142^{\mathrm{d}}$ & & 0.00847 & & 0.01047 \\
\hline $\mathrm{BCa}$ & & 0.01060 & & 0.00924 & & 0.00223 & & 0.00268 \\
\hline
\end{tabular}

Table 3. Multiplier for tourism in Johor.

\begin{tabular}{ccc}
\hline Multiplier & Value & Category \\
\hline Consumption & 0.31 & Low \\
Investment & 0.75 & High \\
Import & 0.12 & Low \\
\hline
\end{tabular}


and how sensitively the results are interpreted. Nevertheless, this technique can produce valuable information for policymakers and planners.

\section{Acknowledgements}

We thank School of Informatics and Applied Mathematics (SIAM) and Research Management Centre (RMC), Universiti Malaysia Terengganu for supporting this research paper.

\section{References}

[1] Hampton, M.P. (2005) Heritage, Local Communities and Economic Development. Annals of Tourism Research, 32, 735-759. http://dx.doi.org/10.1016/j.annals.2004.10.010

[2] Marcelo, R. and Anja, E. (2011) Prime Minister of Malaysia: Tourism Key to Country's Economic Transformation.

http://media.unwto.org/press-release/2011-10-19/prime-minister-malaysia-tourism-key-co untry-s-economic-transformation

[3] Rochelle, T. (2015) Travel and Tourism Economic Impact 2015 Malaysia. World Travel and Tourism Council.

[4] Kerajaan Negeri Johor Darul Ta'zim (2012) Iskandar Malaysia. http://www.johor.gov.my/en/pelaburan/page/iskandar_malaysia

[5] Keshab, R.B. (2005) Keynesian Models for Analysis of Macroeconomic Policy. University of Hull, UK.

[6] Martín, H.R. (2004) Impact of Tourism Consumption on GDP. The Role of Imports.

[7] Nur Amanina, Z. (2012) Pemodelan Generalized Autoregressive Conditional Heteroskedasticity (GARCH) dengan Pendekatan Kaedah Bootstrap: Kajian Kes Terhadap Data Sukuk. Msc tesis, Jabatan Metematik, Universiti Malaysia Terengganu.

[8] Loutfi, M., Moscardini, A.O. and Lawler, K. (2000) Using System Dynamics to Analyse the Economic Impact of Tourism Multipliers. Proceedings of the 18th International Conference of the System Dynamics Society, Albany, August 2000, 132-232.

[9] Archer, B.H. (1976) Anatomy of a Multiplier. Regional Studies, 10, 71-77. http://dx.doi.org/10.1080/09595237600185071

[10] Candela, G. and Figini, P. (2012) The Economics of Tourism Destinations. Springer, Berlin Heidelberg. http://dx.doi.org/10.1007/978-3-642-20874-4

[11] Pascual, L., Romo, J. and Ruiz, E. (2006) Bootstrap Prediction for Returns and Volatility in GARCH Models. Computational Statistic and Data Analysis, 50, 2293-2312. http://dx.doi.org/10.1016/j.csda.2004.12.008

[12] Sousa, S.I.V., Martins, F.G., Alvim-Ferraz, M.C.M. and Pereira, M.C. (2007) Multiple Linear Regression and Artificial Neural Networks Based on Principal Components to Predict Ozone Concentrations. Environmental Modelling \& Software, 22, 97-103. http://dx.doi.org/10.1016/j.envsoft.2005.12.002

[13] Khan, H., Seng, C.F. and Cheong, W.K. (1990) Tourism Multiplier Effects on Singapore. Annals of Tourism Research, 17, 408-418. http://dx.doi.org/10.1016/0160-7383(90)90006-D

[14] Chase, G.L. and McKee, D.L. (2003) The Economic Impact of Cruise Tourism on Jamaica. Journal of Tourism Studies, 14, 16-22.

[15] Paudyal, S. (2012) Does Tourism Really Matter for Economic Growth? Evidence from Nepal. NRB Economic Review, 24, 48-66. 
[16] Nurul Hila, Z. (2014) Pemodelan Model Gerakan Garisan Tengah Purata Bergerak Berpemberat Secara Eksponendengan Pendekatan Cangkuk But. Msc, Jabatan Metematik, Universiti Malaysia Terengganu.

[17] Juzilawati, K. and Tamat, S. (2011) Analisis PelaburanS wasta di Malaysia. Prosiding PERKEM Vi, Jilid 1, 512-522.

[18] Wanhill, S. (1994) The Measurement of Tourist Income Multipliers. Tourism Management, 15, 281-283. http://dx.doi.org/10.1016/0261-5177(94)90045-0

Submit or recommend next manuscript to SCIRP and we will provide best service for you:

Accepting pre-submission inquiries through Email, Facebook, LinkedIn, Twitter, etc.

A wide selection of journals (inclusive of 9 subjects, more than 200 journals)

Providing 24-hour high-quality service

User-friendly online submission system

Fair and swift peer-review system

Efficient typesetting and proofreading procedure

Display of the result of downloads and visits, as well as the number of cited articles

Maximum dissemination of your research work

Submit your manuscript at: http://papersubmission.scirp.org/ 